\title{
L Usioersily
}

\section{Have no doubt it is fear in the land: An exploration of the continuing cycles of violence in South Africa}

Hamber, B. (1999). Have no doubt it is fear in the land: An exploration of the continuing cycles of violence in South Africa. Zeitschrift für Politische Psychologie, 7(1-2), 13-128.

Link to publication record in Ulster University Research Portal

Published in:

Zeitschrift für Politische Psychologie

Publication Status:

Published (in print/issue): 01/01/1999

\section{Document Version}

Publisher's PDF, also known as Version of record

\section{General rights}

Copyright for the publications made accessible via Ulster University's Research Portal is retained by the author(s) and / or other copyright owners and it is a condition of accessing these publications that users recognise and abide by the legal requirements associated with these rights.

\section{Take down policy}

The Research Portal is Ulster University's institutional repository that provides access to Ulster's research outputs. Every effort has been made to ensure that content in the Research Portal does not infringe any person's rights, or applicable UK laws. If you discover content in the Research Portal that you believe breaches copyright or violates any law, please contact pure-support@ulster.ac.uk. 


\title{
„Have no doubt it is fear in the land“. An exploration of the continuing cycles of violence in South Africa ${ }^{1}$
}

\author{
Brandon Hamber ${ }^{2}$
}

\begin{abstract}
Zusammenfassung:
Der Autor beschreibt auf anhand statistischer Zugänge die Gewaltentwicklung in Südafrika von den 70er Jahren bis heute: Unter dem Apartheid-Regime äußerte sich Gewalt als vertikale bzw. strukturelle gegenüber den Bürgern, dehnte sich zunehmend jedoch auch horizontal - innerhalb der Kommunen - aus und erreichte ihren Höhepunkt in den 90er Jahren zur Zeit der Demokratiebewegung. Gründe für diese paradox anmutende Entwicklung sieht der Autor u.a. in der durch das ApartheidRegime verursachten sozialen Ungleichheit, Deprivation und Marginalisierung breiter Bevölkerungsgruppen, der Legitimierung der vom Staat ausgehenden strukturellen Gewalt, der Gewalt seitens der Polizei bis hin zur Folter, sowie der meist ausbleibenden gerichtlichen Verurteilung der Täter und und dem unzureichenden Opferschutz. Die meisten politischen Gruppierungen haben aus diesen Gründen bis in die 90er Jahre Gewalt zum Selbstschutz und zur Selbstjustiz befürwortet, da das die einzige Möglichkeit der Verteidigung und des Umgangs mit den gesellschaftlichen und politischen Realitäten sei. Die Parteien greifen das Thema Gewalt aktuell immer wieder auf, schüren vorhandene Ängste und instrumentalisieren das Problem für Wahlkampfzwecke. Erforderlich ist hingegen eine differenzierte Analyse der Ursachen und Risikofaktoren, um mit Hilfe von Interventions- und Präventionsprogrammen gezielt in die Gewaltspirale eingreifen zu können. Die Regierung sollte bereit sein, auf demokratischer, sozioökonomischer und juristischer Ebene langfristig in eine Menschenrechtskultur zu investieren und Hilfen dafür auf allen Ebenen anzubieten.
\end{abstract}

Have no doubt it is fear in the land.

For what can men do when so many have grown lawless? Who can enjoy the lovely land, who can enjoy seventy years, and the sun that pours down on the earth, when there is fear in the heart? Who can walk quietly in the shadow of the jacarandas, when their beauty is grown in danger? Who can lie peacefully abed, while the darkness holds some secret?

What lovers can lie sweetly under the stars, when the menace grows with the measure of their seclusion? There are voices crying what must be done, a hundred, a thousand voices. But what do they help if one seeks counsel, for one cries this, and one cries that, and another cries something that is neither this nor that. (Alan Paton, Cry The Beloved Country, 1949) 


\section{Creating a Culture of Violence}

The decade of the 1980s was one of the most violent periods in South African history. This period was characterised by the extensive use of force by the South African state and those opposing. This violence was typified by arbitrary arrests, detention without trial, civil unrest, acts of sabotage, harassment, torture, "disappearances" and the murder of political opponents and rivals (Cock, 1990). Most of violence during the 1980s was orchestrated by the state and was targeted at victims both inside and outside the borders of South Africa. Many of the victims were very young and generally the families and relatives of these activists also suffered varying degrees of harassment and direct physical harm. This type of political violence has received enormous coverage in the media and in recent exposures by the Truth and Reconciliation Commission (TRC) and could be termed vertical violence, i.e. violence perpetrated by the state against its citizens.

There was also violence between rival political and social groupings, as well as armed resistance by the liberation forces. As a result, South African society was placed under continual stress of potential violence, either through acts of sabotage as the liberation movement resisted state control, or, as was more often the case, through living in dangerous, tumultuous and tightly policed townships. By the 1990s, the term "culture of violence" was frequently used to describe the conflict that enveloped South African society (cf. (Vogelman \& Simpson, 1990). The pervasive nature of this violence seeped into all parts of public life, undermining the moral, interpersonal and social fabric of society.

Paradoxically, however, it was the years directly after February 1990 (when it was announced that the ANC was to be unbanned and Nelson Mandela released) that the violence reached its peak. The early period of transition to democracy in South Africa (1990-1994) was marked by unprecedented inter- and intra-community violence that largely played itself out, with the assistance of covert state operatives and funding, in the form of armed conflict between supporters of the African National Congress (ANC) and the Inkatha Freedom Party (IFP).

The violence during the 1990s stemmed directly from the intensification of the civil war in KwaZulu/Natal that rapidly spread to the other provinces (TRC Final Report, Volume 2, Chapter 7, 8). Simpson and Rauch (1991) argue that the negotiations in the early 1990s facilitated a process of deregulating the overly repressive forms of social control that had characterised the apartheid state. The effects of the violence, which had been legitimised by all political groupings in the decades prior to the 1990s, lingered in a context in which the mechanisms for social control (e.g. the state security forces) enjoyed even less legitimacy than before. In the context of the negotiated sett- 
lement, the repressive forms of control used by the apartheid government were rendered ineffective, yet no viable alternative was generated by the haphazard and slow process of negotiated transition. This created the space for political parties (such as the IFP) to freely use violence to build their local and national support bases. At precisely the point when the society was moving toward democracy, political and criminal violence escalated. This was created largely by a vacuum in state authority and heightened competition between political parties. Paradoxically this was the direct result of the processes of negotiated constitution-making that were essential to ensuring democracy.

In the mid-1970s, political violence killed on average 44 persons a month. By the mid-1980s, this figure had risen to 86 , and by the early 1990 s it was 250 (SAIIR, 1993). The nature of violence in the early 1990s also changed, from vertical (i.e. the state against its citizens and the citizens against the state) to horizontal (i.e. fellow citizens against one another). In the 1970s and 1980s the police were responsible for most deaths. By the 1990s intra-community and intra-organisational conflict in the townships and rural areas (some covertly sponsored by the state and its agents) accounted for the greatest number of fatalities. Over the period of the negotiations from February 1990 to April 1994, as South Africa was supposedly normalising, 14,807 people were killed, according to the South African Institute of Race Relations. This is in stark comparison to the previous five years, when the Institute reported 5,387 deaths from political violence.

It should be noted that the divisions between what is labelled as 'political' violence and what is termed 'criminal' violence in South Africa has always been blurred. This accounts for some discrepancies between different agencies' statistics on fatalities. In addition, relativising (and approximating) the number of fatalities should be used cautiously. Statistics cheapen the lives of each individual killed and also obscure other forms of repression. Looking at the number of deaths that took place in 1980s alone does not tell the whole story. For example, between 1984 and 1986 the South African police shot dead 300 children, wounded 1,000, detained 11,000 without trial, arrested 18,000 on charges relating to political protest and held a further 173,000 in police cells awaiting trial (CIIR, 1996).

Since the first democratic election in April 1994 reports of political violence have decreased although not disappeared. In 1997, the Human Rights Committee reported that more than 300 people in Kwazulu-Natal and 151 people in the rural Eastern Cape had been killed in political violence.

The South African Institute for Race Relations Reported that 470 people died in political feuds in 1997.

Between 1 January 1998 and 31 July 1998 a further 218 people had lost their lives due to political conflict (SAIRR, 1998) suggesting a slight increase in political violence with the advent of the second democratic election. 
Although alarming, this is significantly lower and more manageable than it had been in the years immediately preceding the first democratic election. Despite sporadic clashes between the ANC and the Inkatha Freedom Party, as well as recent violence between ANC members and the newly formed United Democratic Movement (UDM), it is unlikely that political violence will reach its pre-1994 levels. This is due to the current ANC-IFP détente (Chothia, 1999) and because peace between the parties appears to be consolidating Nonetheless, the threat of violence has not been totally removed.

\section{Violence in Contemporary South Africa}

In South Africa today political violence is totally over-shadowed by the high levels of violent crime the country is experiencing. Recent trends show increased levels of crime from 1990 to the present.

It should be noted that there are variances in incidence among different crimes and some have, in fact, been declining since 1990 and specifically after 1994. For example, murder rates, although still high, have been declining since 1994. The murder rate in South Africa has been steadily dropping since 1994. It was approximately 67, 65, 61 per 100,000 in 1994, 1995,1996 respectively.

Concerns about ongoing political violence have been deflected and deprioritised. Comparatively speaking, the incidence of violence in South Africa is extremely high. In 1997, the homicide rate for South Africa was estimated at about 57 per 100,000 inhabitants. This is compared to approximately 9 per 100,000 in the United States and 1 per 100,000 in the United Kingdom. In Columbia, when the Medellin drug cartel was operating in the city of Medellin in 1993, the homicide rate was an alarming 450 murders per 100,000 (Roelefse-Campbell \& Campbell, 1996a). Countries such as Brazil, which have more comparable histories to South Africa, show similar yet less dramatic trends in violent crime (Roelefse-Campbell \& Campbell, 1996b). Brazil witnesses on average 39,000 murders a year, compared to the approximate 25,000 in South Africa, a country with about one third of the population.

Furthermore, the experience of being violently victimised in South Africa has almost become a statistically normal feature of everyday life in the many urban and rural settings in South Africa. Statistics released in January 1999 by the Minister of Safety and Security showed that incidents of car hijacking, armed robbery, vehicle theft and burglary were all higher than in 1997 (Cawthra \& Kraak, 1999). New statistics show that 188 out of every 100,000 South Africans were victims of armed robbery in 1998 while the figure for car hijackings was 33 (Cawthra \& Kraak, 1999). The report, however, also 
shows that some serious crimes such as murder, rape and bank robberies have declined from the previous years.

Despite declines in the incidence of rape the situation remains grave. In 1997, 52,160 rapes were reported to the South African Police Service (South African Police Services, Quarterly Report, 1/98). These statistics, however, are likely to underestimate the exact incidence of rape. The National Institute for Crime Prevention and Reintegration of Offenders (NICRO 1993) estimates that only 1 in 20 rapes are ever reported to the police. NICRO, therefore, speculates that a rape occurs in South Africa every 83 seconds. If this estimate is accurate, then at least one million women were raped in 1997.

Although these statistics can be useful in making broad comparisons, the figures need to be understood in context. In South Africa, there are flashpoints of violence and the statistics generally indicate national averages (which are often disputed and are notoriously unreliable at times). In reality the probability of being murdered in certain areas (for example, wealthy suburbs) remains significantly lower than in other areas. The statistics may produce a high total, but pockets of relative safety still exist when compared to other dangerous areas that inflate the national means. High national statistics often erroneously lead to perceptions that violent crime is uniform and pervasive across all communities when this is not the case.

Recent police statistics support the view that violent crime is by no means uniform across the country. For example, homicide rates in South Africa are highest in the rural areas and not in the urban centres as is often presumed. The mainly rural provinces of the Free State, Kwazulu-Natal and Mpumalanga are the murder and hijacking capitals of South Africa according to the report released by the Minister of Safety and Security in January 1999. The more rural provinces and less economically developed areas such as the Northern Cape also show the highest incidence of reported rape (CIMC, 1997). Ironically, these are the areas with the most limited psycho-social support services for woman and children.

Race also remains a primary predictor of violence in South Africa. There is a popular perception (largely held by white South Africans) that the wealthy are more affected by crime than the poor. This is at best only partly true. The rich are twice as likely to be victimised (usually predatory property crimes) than the poor, but the poverty-stricken are nearly 80 times more likely to die or get hurt by crime than the well-off (Steinberg, 1999). Furthermo$\mathrm{re}$, the annual incidence of violence experienced by African women is more than ten times that of their white counterparts (Trauma Review, 1996). These figures are in line with the increasing international evidence that poor people bear most of the brunt of violence in society (cf. Mercy, Rosenberg, Powell, Broome \& Roper, 1993; Louw \& Shaw, undated; HSRC survey cited in Louw \& Shaw, undated). 
Social inequality and enormous deprivation caused by the apartheid system are at the root of most violence in South Africa. But violent crime in South African society as a phenomenon has other multiple causal factors that extend beyond deprivation. Some of these include, to mention a few, a patriarchal society where women and children are devalued and vulnerable; the historical development of a culture of violence where violence was seen by all significant political parties as a legitimate means to achieve their goals; the deregulation of state control during the negotiations period; an ineffective criminal justice system and the perception that there will be no serious consequences for criminal activity; and the opening of South African borders to criminal syndicates and operations since the shift to democracy has also had some impact on rising levels of crime (cf. Hamber, 1998a; NCPS, 1996; Simpson, 1993; Simpson \& Rauch, 1991).

\section{The Continuing Cycles of Violence}

It is undoubtable that the current levels of violent crime and its multiple manifestations have been built on the legacy of the civil conflict of the past. The extensive nature of politicisation in South Africa has ensured that a "culture of violence" has bled into the social and civic arena of society (Simpson \& Rauch, 1991). The structural violence effected by the state through inequalities of resource and life chances in the past, coupled with repression, politicised all forms of social existence (e.g. housing, education, jobs, wages, the delivery of services, etc.). The result is that the socially sanctioned use of violence to solve problems has saturated South African life (Simpson \& Rauch, 1991). This manifested itself most dramatically in the 1990-1994 period prior to the first democratic election and is continuing to play itself out in the postapartheid era.

The perpetuation of the past and its dangerous impact on the present in South Africa is eloquently captured by Cawthra and $\operatorname{Kraak}(1999,36)$ when they write:

"the decades in which the police enforced apartheid have engendered a lingering mistrust of the rule of law and authorities. But crime is also intrinsically linked to poverty, unemployment, socio-economic inequalities and gender inequality. The coalescence of these indices with the brutalisation that many experienced during the anti-apartheid struggle, has given crime in South Africa its particularly violent edge".

Morris (1987) asserts that victims of criminal violence, if untreated, are at risk of perpetrating acts of retributive violence, or for displacing their aggression within the familial context. Some victims of violence in South Africa 
have begun committing violent acts themselves - these actions are often associated with vigilantism and self-administered "justice". Increasing reports of this type of community and individual action against suspected criminals has been reported (Weekly Mail, 1997). A nation-wide survey by Market Research Africa in 1997 indicated considerable support for vigilantism among black South Africans; one fifth of black respondents believe that it was 'sometimes right for a vigilante group to physically hurt a suspected criminal' (Schönteich, 1999). It is likely that these results would not differ fundamentally in the white community.

Summary justice carried out by community members is a frequently preferred alternative to the criminal justice system. It appears, at least on the surface, to be quicker and a more direct method of dealing with crime. The majority of South Africans view the criminal justice system with suspicion and scepticism. This is not surprising considering that one in seven murders, one in 13 reported rapes, one in 34 armed robberies, one in 50 car thefts and one in 55 car hijackings results in a conviction (Cawthra \& Kraak, 1999; Steinberg, 1999). Forty-one percent of South Africans would either "never" or "hardly ever" trust the police to investigate a crime or catch criminals (Reality Check, 1999).

However, mistrust of the police service hardly equates with uncensored vigilantism. Vigilantism is seriously undermining South Africa's embryonic human rights culture. Unregulated "people's justice" leads to abuses and the transgression of human rights (Cawthra \& Kraak, 1999). At present vigilantism represents one of the most fundamental challenges to the human rights culture in South Africa (Pigou, Valji \& Greenstein, 1998).

Within the wealthier areas in South Africa "vigilantism" is being carried out in another form. The lack of faith in the criminal justice system by many wealthy South Africans has lead to increasing numbers of citizens turning to private security companies for their policing needs. It is estimated that the private security industry in South Africa has grown from R 141 million in 1978 to R 8 billion currently (Schönteich, 1999; R 10 is the equivalent of about one pound sterling). There at least twice as many security guards as policeman in the country (NIM, 1997). Many of these guards are poorly trained and armed, and the security industry is poorly regulated. Schönteich (1999) links the phenomenon of private security and vigilantism. He writes:

Most people cannot afford the services of a private security company. Vigilantism is often the poor man's version of private security, and the poor are hit hardest by crime. Out of desperation they seek to protect themselves, or they seek to protection in numbers through the organisation of groups which often engage in, or encourage, vigilante action (p. 18). 
The legacy of a "culture of violence" also still permeates the police services. Gross human rights violations persist in the police service despite the end of apartheid. In the months April 1997 to September 1998 it was reported by the Independent Complaints Directorate that 1,081 people died in police custody, or as a result of police action. (The Independent Complaints Directorate is a statutory body that was set up in April 1996 to investigate complaints against the police.) This may point to ongoing levels of impunity within the police services and insufficient checks and balances in terms of police operations despite a formal democratic disposition. The torture of criminal suspects by the police is continuing. The Independent Complaints Directorate received 73 complaints about police torture over the 18 month period of April 1997 to September 1998, a figure which is suspected to hopelessly under-represent the abuses that are taking place.

It is interesting to note that the torture of criminal suspects has always been a phenomenon in the South African police service. It was a practice that was taking place along side the torture of political suspects during the apartheid era. A report released in 1995 (IBI, NIM \& Trauma Centre for Victims of Violence and Torture, 1995) highlighted 350 cases of police torture of criminal suspects between 1990 and 1995. It argues that, although not well documented, the torture of criminal suspects may well have been higher than the torture of political dissidents under the apartheid regime.

South Africa, like countries such as Brazil, Argentina and Chile (cf. Hamber, 1997; Pinheiro, 1994; Pinheiro, 1996), seems to be suffering from ongoing authoritarianism and resultant human rights violations by the police. This is happening despite the instatement of democratic governance and the investigations carried out by the TRC into the past activities of the police. There is little evidence, at least at this stage, that the TRC's exposure of police atrocities committed in the past are generalising into the current work of the police service. If anything, the high rates of crime in South Africa are paradoxically giving the police a freer hand to commit violations. The public is increasingly advocating tougher anti-crime measures due to their fear of rampant crime. A recent survey revealed that $70 \%$ of South African respondents either agreed or strongly agreed with the statement that "criminals have too many rights" (Reality Check, 1999). In addition, $31 \%$ of all South Africans feel the police have the right to use force to extract information from criminal suspects (Pigou, Valji \& Greenstein, 1998).

Despite the TRC's efforts in its final report to highlight ongoing police abuses (see TRC Final Report, Volume 5, Chapter 8,68), it appears that in the minds of the general public the atrocities committed by the police under the apartheid system are considered fundamentally different to those currently taking place. The TRC has unwittingly exacerbated the situation by trying to artificially delineate between political and criminal violence - a distinction, 
which in most cases is impossible. It remains questionable to what degree the TRC has adequately exposed, understood and consequently impacted upon the current culture of the police service.

The TRC has been relatively successful at uncovering the truth about atrocities of the past through its trade of truth for justice.

Some would argue that the TRC has only uncovered a small section of the 'truth' in South Africa. In parts of the country very little new information has emerged. For example, in the Vaal region outside Johannesburg, a site of extensive political violence including a number of massacres, only three South African policeman have applied for amnesty.

During the negotiations that ensured South Africa's first democratic election the ANC did not have sufficient power to demand prosecutions of former human rights abusers (and in reality the criminal justice system in South Africa probably did not have the resources or efficiency to prosecute large numbers of individuals anyway). However, it had sufficient power to prevent the NP from granting itself blanket amnesty. The balance of power tipped slightly in favour of the ANC gave birth to a criterion-driven amnesty process. Amnesty would be granted only on condition that the crime was political in nature and that the individual fully disclosed all of the details of the act for which amnesty was sought. In essence, truth was traded for formal justice. The function of deciding on amnesties fell on the TRC.

However, the exact impact of amnesty (with or without the truth being forced from the perpetrators) on ongoing levels of impunity is not yet fully understood. Despite the full disclosure of the atrocities of the perpetrators through the TRC, and the TRC highlighting them in its final report, perpetrators have largely not been punished for gross violations of human rights. Contrary to Article 2.2 of the Universal Declaration of Human Rights that states that no exceptional circumstances whatsoever may be invoked as a justification for torture, several torturers from both the apartheid state and the liberation forces, have been granted amnesty for their actions which were considered "political". As a result, a subtle, but stubbornly residual air of impunity still lingers in the South Africa society and in its police service.

This has happened within a context of high crime rates and where the criminal justice policies have become increasingly politicised. The politicisation of crime has obscured the real challenges facing crime prevention and the development of a sustainable human rights culture. All parties contesting the second democratic election in June 1999 used the issue of crime as a major political rallying point. Most of their campaigns exploited the fears of the population that crime is spiralling out of control. This fed the already rampant fear that permeates much of the current South African mindset. Crime rates are genuinely high, but the general population's fear of victimisation is on the whole out of proportion to the real threat. This ongoing fear and anxiety, often spurred on by politicians who want to portray the country as being mis- 
managed by the current government, further traumatises the already vulnerable population. The impact of the psychology of fear is captured by Hamber and Lewis (1998) when they write:

"It is this situation, understandable and realistic as it is on some levels, that makes us see violence in our society as spinning increasingly out of control, even when it is not. In the long run, this fuels a sense of helplessness in the society - in turn, psychologically empowering the criminals and preventing us from finding solutions" (Crime's worst horror is all in the mind, Sunday Times, 1 March 1998).

The exact and pervasive nature of the fear and anxiety that has been created by crime in the post-apartheid South Africa remains an under-researched area. However, it is likely that the current levels of fear in the society is, at least in part, a symptom of the traumatisation that took place during the struggle to overthrow and defend the apartheid state. Fear impacts on the population increasingly uncritically accepting mono-causal explanations for crime. Political rhetoric such as "Hang Murders and Rapists" (New National Party slogan) and the Democratic Party's haunting election radio adverts that list endless acontextual statistics about individuals chances of being victimised ride on a wave of fear. Along with the years of apartheid, which undermined all South Africans' basic understanding of human rights and legitimised the use of violence across the board, this political rhetoric feeds into simplistic understandings of the causes of violence and appropriate solutions. For example, $92 \%$ of Indians, $91 \%$ of whites, $85 \%$ of so-called coloureds and $68 \%$ of Africans in South Africa favour the reintroduction of the death penalty (Reality Check, 1999). Both black and white South Africans naively believe that reintroducing the death penalty will seriously curb violent crime.

South Africa's fragile human rights culture is being incapacitated. All the major political parties have largely retreated from their human rights principles under the weight of popular mono-causal explanations for crime. The view that violence is differentially spread and that localised prevention strategies are the best option to ameliorate some types of crime is becoming increasingly lost in South Africa.

The ongoing fear in the society not only disempowers the population, but when action is taken it seems to take the form of more drastic and extreme interventions. This is typified by "people's justice" and ongoing police abuses which are, in part, fuelled by feelings of fear. Fear (and the ongoing legacy of the traumas of the past) drive individuals to feel that it is necessary to go to extremes to curb crime. Clearly, if ignored, certain victims of past violence are at risk of becoming the perpetrators of retributive violence or displaced social and domestic violence (NCPS, 1996; Simpson, 1996). 
A recent survey in South Africa found that a one in five men and one in ten woman felt that it was sometimes necessary to hit a woman partner (Pigou, Valji \& Greenstein, 1998).

The recent trends in increased violence through vigilantism and the ongoing use of political revenge and retribution in Kwazulu-Natal, bear testimony to this thesis.

The National Crime Prevention Strategy (1996) recognises this danger, and argues that in the case of violent crime, victim empowerment and effective support can break the cycle of violence and therefore can be viewed as preventative. Trauma counselling and a range of other interventions (e.g. victim-care strategies such as the establishment of crisis centres) with traumatised individuals, would be effective in alleviating and preventing the consequences and effects of violent victimisation. The TRC Final Report also recognises the need for appropriate models for trauma counselling in the South African context to be developed and implemented (Volume 5, Chapter 8, 86).

\section{Breaking the Cycles of the Past}

In South Africa the legacy of the past and how it destructively plays itself out in the present needs to be fully understood if current levels of violence are to be adequately addressed. This has happened through the TRC to some degree, but the lessons from the past highlighted by the TRC show little evidence of generalising to the current context in South Africa. The double-bind when dealing with the aftermath of large-scale political violence is that acknowledgement, apology, recognition and even substantial material improvement can never bring back the dead or be guaranteed to converge with, and ameliorate, all the levels of psychological pain suffered by a survivor (Hamber, 1998b). Nor is rapid economic progress a panacea to deal with the longterm effects of political violence. Unfortunately, the amount of distress, hurt, injustice and anger experienced by the survivor is immeasurable. Strategies to assist those who were victimised in the past need to continue. There is a grave danger that the plight of the survivors of past violence will be ignored now that the TRC is officially over.

Furthermore, those politically victimised in the past remain at the highest risk of victimisation in the current context. The majority of survivors who appeared before the TRC were victimised not only because of their political affiliation and activities, but because of their structural circumstances including their gender, poverty, race and general social marginalisation (Hamber \& Kibble, 1999). The structural circumstances of most of these individuals remain largely unchanged and their social marginalisation remains 
the primary risk factor for them being victims of violent crime in the current context.

The voices of these survivors, who could now potentially be revictimised, will undoubtedly be heard for many years. On a purely psychological level, for a survivor to react in an overly forgiving way toward perpetrators, or to simply let bygones be bygones, is highly improbable in the shortterm with or without a truth commission (Hamber, 1998c). The TRC has been a catalyst for successful resolution of this kind in some cases. However, when the TRC is complete, and reparations are granted, psychologically most survivors will not be ready to put the past behind them at that specific point. Furthermore, if they are re-victimised, even if this is re-victimisation is not political in nature and is purely criminal, their chances of reconciling themselves with the violence of the past remain slim. This will have a long-term impact on the political project of reconciliation that was pursued by the TRC.

Ongoing space has to be provided for survivors to express their feelings of sadness and rage as they struggle to come to terms with the psychological and emotional impact of their past loss and that much in their current structural situation remains unchanged. Survivors of apartheid violence cannot be pushed down the road of forgiveness and amnesia if they are not ready purely because it is nationally expedient. These spaces can take the form of private spaces (e.g. counselling, traditional mechanisms for story-telling and sharing, etc.) and the ongoing use of public space (e.g. media, exhibitions, etc.). At the same time accurate information is needed if violence is to be restricted. Reliable epidemiological data is desperately needed in South Africa. Accurate data collection could identify risk factors for violence (e.g. substance abuse, fire-arms, etc.) and violence "hot-spots", and in so doing contribute to targeted and directed intervention strategies.

The proliferation of firearms, particularly small arms, is one of the major factors in the high incidents of violence in South Africa. It is estimated that there are 11 to 13 million firearms in South Africa, 4 million are legally owned, 1 to 4 million illegally held and about 5 million belong to the Defence Force and Police Service (NCPS, 1996). 11,190 people were killed with firearms in 1997 (Gun Free South Africa Statistics Sheet, 7 April 1999).

The needs of survivors of political violence also cannot be divorced from the socio-economic context. Economic disparity in South Africa remains stark. The standard of living of average black South Africans is comparable to the 124th most wealthy nation in the world (after Congo), whereas for the average white South African it is comparable to the 24th (after Spain; United Nations Development Programme figures cited in Villa-Vicencio 1998).

If inequality persists, the tide of unmet expectations and the rise of a perceived new black elite may lead the general populace to complain (and protest) about structural conditions. 
Despite the growth in the black middle class in South Africa the plight of the very poor is not improving. Over 4 million blacks now compromise more than half of the top-income earners in the country, but there has been a decline in wealth among the 25 million people - about $60 \%$ of the total - who are poor (Hawthorne, 1999).

In the worst case scenario survivors who appeared before the TRC may even start to feel that they were the pawns in the process of reconciliation and consolidation of new forms of power. They could then see the TRC as a process that ignored their poverty, but used their voices to ensure greater levels of political co-existence between the elites in the name of reconciliation.

A further concern is that in societies going through transition it is often the large scale political conflict and criminal violence, and particular brutal acts of violence, that tend to receive attention at the expense of the more hidden costs of violence. The micro-effects of violence that ripple through communities generally go unnoticed. For example, violent intra-community conflict can cause the destruction of the social fabric and culture of communities, and disrupt schooling, resulting in incremental disadvantage over time.

Critically the violence of the 1990-1994 period has not been dealt with to the same extent as the violence in the other periods. Relatively speaking the horizontal violence that took place within communities (which accounted for the most fatalities) has been sorely neglected despite all South Africa's attempts at reconciliation. The TRC admits to have "failed to make significant breakthroughs in relation to violence in the 1990s" (Volume 5, Chapter 6, 54). It is further notes:

"While Commission figures for reported violations in the earlier part of its mandate period are under-represented in part because of the passage of time, they are under-reported in this later period because the abuses are still fresh in people's memories and closely linked into current distribution of power incidents" (TRC Final Report, Volume 2, Chapter 7, 7).

Of 9,043 statements received on killings, over half of these $(5,695)$ occurred during the 1990 to 1994 period. These figures give an indication of violations recorded by the Commission during the negotiations process (TRC Final Report, Volume 2, Chapter 7, 7).

It is vitally important that it is acknowledged that the apartheid past has left a legacy of violence and mistrust within communities themselves and not merely between the state and its citizens. Many communities in South Africa remain internally conflicted and divided. These divisions have only been partially dealt with by the Truth and Reconciliation Commission (cf. van der Merwe, 1998). It is within communities, and at the local level, where future conflict is likely to manifest itself. This will occur when new power struggles emerge, as leaders vie for the support of the marginalised sections of the population. In this context, disaffected individuals, and those who feel their 
rights to justice under the amnesty laws were sacrificed for minimal return in the past, and whose structural conditions remain unchanged, who will become the first recruits of political entrepreneurs who will exploit past resentments.

All of South African society has been traumatised to some degree. This requires the type of social and political rehabilitation policy the TRC has partly championed. The need for ongoing individual medical and psychological support services to thousands of victims of past and current levels of violence remains a national priority. In addition, where societal functioning and cohesion has been damaged, or where there is abject poverty, repairing community and cultural bonds and structures may be as important as psychological assistance.

The history of conflict in South Africa teaches us that, on the backbone of a fragile social fabric undermined by years of apartheid's destruction, political tensions often result in violence that spreads horizontally across communities. The compromises between all parties that resulted in peace in South Africa helped quell this type of violence before, but not before an excessive loss of life and the erosion of the social fabric. Today in South Africa the situation is very different. The legacy of the violence of the past lives on, but political consensus is no longer the key to a stable political environment. Rather what is needed is a mature government that is prepared to invest in the long term. Such a government would welcome critical evaluation of their achievements, invest energy in genuine economic re-distribution and continue to forward an unequivocal human rights agenda. Stability in the long term requires the government to stand by their human rights policies and not to retreat from them, despite the misplaced fears of the population that it is the new human rights-orientated dispensation that has resulted in a rise in violence in post-apartheid South Africa.

\section{Anmerkungen:}

(1) My thanks to Hugo van der Merwe, Piers Pigou, Gareth Newham and Helen McLaughlin for their editorial comments and suggestions.

(2) Brandon Hamber is the co-ordinator of the Transition and Reconciliation Unit at the Centre for the Study of Violence and Reconciliation, Johannesburg, South Africa. Visiting Tip O'Neill Fellow at the Initiative on Conflict Resolution and Ethnicity (INCORE) in Derry, Northern Ireland. All purpose e-mail: brandon@wn.apc.org. 
Centre for the Study of Violence and Reconciliation, P.O. Box 30778, Braamfontein, 2017, Johannesburg, South Africa. Tel: +27 (11) 403-5650 Fax: +27 (11) 339-6785. Website: http://www.wits.ac.za/csvr. 


\section{References}

Cawthra, H. C. with Kraak, G. (1999). Annual Review: The Voluntary Sector and Development in South Africa 1997/1998. Development Update. South African National NGO Coalition \& INTERFUND: Johannesburg.

Chothia, F. (1999). The Invisible Détente. Siyaya, Issue 4, Autumn, pp. 25-29. Idasa: Cape Town.

CIMC (1997). The Incidence of Serious Crime between 1 January and 31 March 1997. Crime Information Management Centre (CIMC), National Detective Service, Pretoria. 13 June 1997.

CIIR (1996). South Africa: breaking new ground. Published by the Catholic Institute for International Relations (CIIR), London, U.K.

Cock, J. (1990). Political Violence. In B.W. McKendrick and W.C. Hoffman (Eds), People and Violence in South Africa. Oxford University Press: Cape Town.

Hamber, B.E. (1997). Living with the Legacy of Impunity: Lessons for South Africa about Truth, Justice and Crime in Brazil. Unisa Latin American Report, 13(2), JulyDecember pp. 4-16. Unisa Centre for Latin American Studies, University of South Africa: Pretoria.

Hamber, B. (1998a). Dr Jekyll and Mr Hyde: Problems of Violence Prevention and Reconciliation in South Africa's Transition to Democracy. In E. Bornman, R. van Eeden \& M. Wentzel, Violence in South Africa: A Variety of Perspectives. HSRC: Pretoria, South Africa.

Hamber, B. (1998b). Repairing the Irreparable: Dealing with double-binds of making reparations for crimes of the past. Paper presented at the African Studies Association of the UK Biennial Conference "Comparisons and Transitions" at SOAS, University of London, London, 14-16 September 1998.

Hamber, B. (1998c). Remembering to Forget: Issues to Consider when Establishing Structures for Dealing with the Past. In B. Hamber (ed.), Past Imperfect: Dealing with the Past in Northern Ireland and Societies in Transition, pp.56-78, Derry/Londonderry: University of Ulster/INCORE.

Hamber, B. \& Kibble, S. (1999). From Truth to Transformation: South Africa's Truth and Reconciliation Commission. Catholic Institute for International Relations (CIIR): London.

Hawthorne, P. (1999). In gear for growth. Time Magazine, May 24, pp. 58-60.

IBI, NIM \& The Trauma Centre for Victims of Violence \& Torture (1995). Breaking with the Past: Human rights violations allegedly committed by the South African Police Service 1990-1995. Published by the Independent Board of Inquiry Network of Independent Monitors and the Trauma Centre for Victims of Violence \& Torture.

Louw, A \& Shaw, M. (Undated). Stolen Opportunities: The Impact of Crime on South Africa's Poor. Occasional Paper, unpublished.

Mercy, J.A., Rosenberg, M.L., Powell, K.E., Broome, C.V. and Roper, W.L. (1993). Public health policy for preventing violence: New vision for prevention. Health Aff (Millwood), 12, 7-29.

Morris, A. (1987). Women, Crime and Criminal Justice. Oxford: Basil Blackwell.

National Crime Prevention Strategy / NCPS (1996). Document produced by an InterDepartmental Strategy Team consisting of the Departments of Correctional Services, Defence, Intelligence, Safety and Security Justice and Welfare. May, 1996.

NICRO (1993). Every 83 Seconds. Video produced by the National Institute for Crime Prevention and Reintegration of Offenders (NICRO). 
NIM (1997). Safety and Security Report. Network of Independent Monitors: KwazuluNatal.

Pigou, P. Valji, N. \& Greenstein, R. (1998). Assessing levels of human rights knowledge amongst the general population and selected target groups. Community Agency for Social Enquiry (CASE), November. CASE: Johannesburg.

Pinheiro, P.S. (1994). The Legacy of Authoritarianism in Democratic Brazil. In S. Nagel (Ed) Latin American Development and Public Policy. St. Martin Press: USA.

Pinheiro, P.S. (1996). Democracies without Citizenship. NACLA: Report on the Americas, Vol.XXX, Sept/Oct, 17-42.

Reality Check (1999). Reality Check Survey of the Attitudes of South Africans. Cape Times, The Star, The Mercury, Pretoria News, Diamond Fields Advertiser and Sunday Independet. April 281999.

Roelefse-Campbell \& Campbell (1996a). States in the labyrinth: insecurity, crime and cartels in Columbia and Peru. Acta Criminologica, Vol 9, No 2, pp. 16-25.

Roelefse-Campbell \& Campbell (1996b). State and society in the fight against crime in Brazil. Acta Criminologica, Vol 9, No 1, pp. 20-25.

SAIIR (1993). The South African Institute of Race Relations, Fast Facts, No.6, p. 7. SAIIR: Johannesburg.

SAIIR (1998). The South African Institute of Race Relations, Fast Facts, No.9, September. SAIIR: Johannesburg.

Schönteich, M. (1999). Vigilantes: When the judicial system fails... Frontiers of Freedom, Second Quarter, No 20, pp. 18-23.

Simpson, G. (1993). Explaining Endemic Violence in South Africa. Centre for the Study of Violence and Reconciliation. Johannesburg: South Africa.

Simpson, G. \& Rauch, J. (1991). Political Violence 1991. In N. Boister \& K. FergusonBrown (Eds), Human Rights Yearbook, First Edition. Cape Town: Oxford University Press.

Steinberg, J. (1999). Crime: Beyond 2000. Siyaya, Issue 4, Autumn, pp. 47-49. Idasa: Cape Town.

Trauma Review (1996). National Trauma Research Programme of the South African Medical Research Council, Vol 4 (2), August.

van der Merwe, H. The South African Truth and Reconciliation Commission and Community Reconciliation: A Case Study of Duduza. Centre for the Study of Violence and Reconciliation. Johannesburg: South Africa.

Villa-Vicencio, C. (1998). The South African Truth and Reconciliation Commission. Some Guiding Principles: Justice, Amnesty and Reconciliation. Paper presented at the "Burying the Past: Justice, forgiveness and reconciliation in the politics of South Africa, Guatemala, East Germany and Northern Ireland Conference”, Oxford University, Oxford, U.K., 14-16 September 1998.

Vogelman, L. \& Simpson, G. (1990). Current Violence in South Africa. Sunday Star Review, June 171990.

Weekly Mail (1997). 2000 take mob action over crime. Vol.13, No.6, February 14-20, 1997. 